\title{
Staffing a Crime Scene Investigation Unit from Sworn to Civilian: A Solution for Law Enforcement Operations
}

\author{
Peter Joseph Salicco* \\ Forensic Fingerprint Expert, USA
}

Submission: July 21, 2017; Published: August 18, 2017

*Corresponding author: Peter Joseph Salicco, Forensic Fingerprint Expert, Dallas Police Department, USA, Tel: 214 394-4102;

Email: jpsalicco@sbcglobal.net

\section{Introduction}

The recent popularity of forensic science and crime scene investigations depicted on television and in movies has taken a toll on all law enforcement from the small city police department to our country's federal agencies in trying to provide even the simplest of forensic services to the public. Police and sheriff departments across the country may be the hardest hit by requests or the demand for more forensic science applications and services, that prior to the "CSI" popularity surge relied heavily on detectives/investigators to solve cases via interrogations, interviews, confessions and tracking down leads. While detectives still play a very major and vital role in solving crime, the demand for physical evidence to present a case by a district attorney in court and before juries is increasing. This has been coined as the "CSI" Effect which simply stated is the demand by jurors for scientific evidence to convict defendants and the public's expectation for forensic processing of their crime scenes by their own law enforcement agencies. Department dispatchers and call takers are getting calls from victims of burglary of vehicles (often called a BMV) demanding that a CSI be sent to their location because they (the complainant) can see fingerprints (latent prints) on their vehicle at the point of entry.

A call that would normally be handled by a report taker over the phone now becomes a call for service if policy requires it. If the policy does not require a CSI response, the dispatcher or call taker is tasked to advise the complainant that BMV calls for service are a "report only call" and no crime scene response will be dispatched. The call taker or dispatcher then transfers the complainant to a phone report taker. The victim/complainant of the minor crime may take it personally or feel that their police department doesn't care about them or their loss. The department is frustrated because the citizen doesn't understand that it has to use its limited staffing resources on priority calls such as residential burglaries or persons crimes. In some cities or counties, even a residential burglary or business burglary must sustain a substantial loss for a crime scene response to be considered. According to the U.S. Department of Justice, property crime makes up slightly more than three-quarters of all crime in the United States [1,2].

There is a long term solution that involves the crime scene unit personnel, a working crime scene investigator liaison and a voluntary program of field patrol officers willing to perform minor crime scene functions. This paper will explain the differences in the level of crime scene investigation experience that currently exist among sworn and civilian CSIs, and then explore the tier-level civilian crime scene personnel model combined with a voluntary sworn or police Field Crime Scene Investigator as a way to meet the demands of an increasing need for a minor property crime scene response. The by-product of implanting such a program can create good will among the public and the law enforcement agency as well as create a contingent competent crime scene response force. Those participating in the voluntary field crime scene response could eventually be utilized in the event of a major crime incident requiring a substantive personnel response, such as a freeway shooting with numerous victims or a multiple-scene officer involved incident. While the Field Crime Scene Officer would not carry the primary responsibility of the major scene, their help in some aspects could be extremely helpful.

When discussing the demand for forensic services, some would debate that the CSI Effect exists at all, while others believe that there is, at minimum, some validity to the syndrome and attest to increase demand by their citizens for forensic services. For certain, the interest and popularity of crime scene investigations has given shows such as CSI and NCIS, Law and 
Order, and other similar programs successful ratings and continued prominence in the television viewing share, which speaks for itself. The original television show CSI (Las Vegas, Nevada) has even spawned two more successful CSI programs set in Miami and in New York. According to Donald Sheldon in his 2008 paper, The CSI Effect: Does it really exist? The television series CSI is the most watch television show in the world.

The following bullet points and graph are from Sheldon's article:

a) 30 million people watched CSI on one night.

b) 70 million watched at least one of the three CSI shows.

c) 40 million watched a Trace or Cold Case. (Figure 1)[3].

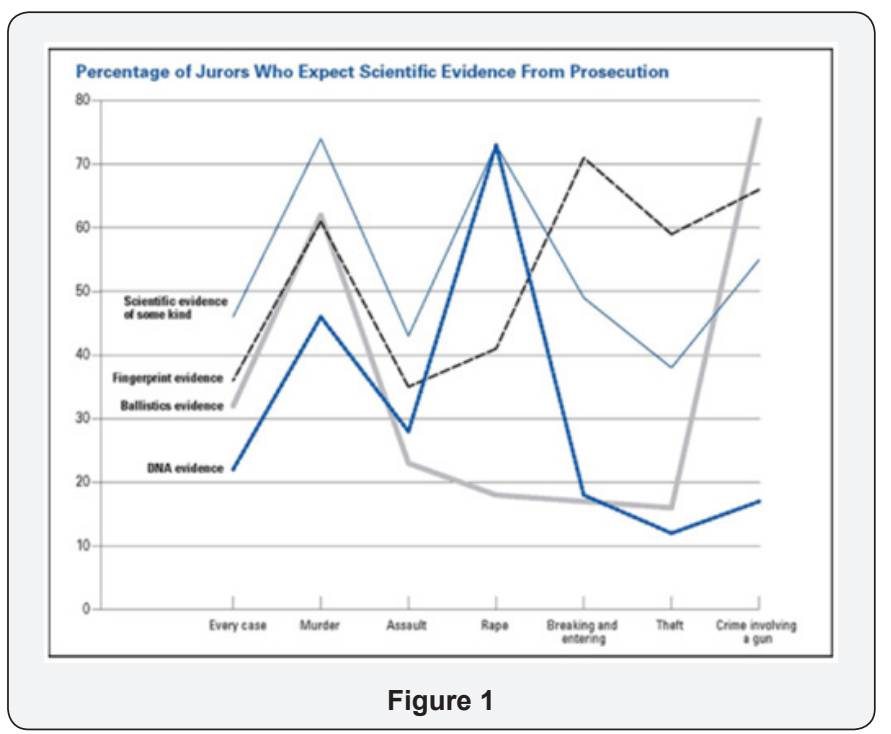

Because they see it on television, the public want to see some effort being made to collect physical evidence of some kind. According to Sheldon's graph, those who watch forensic shows tend to look for specific evidence such as DNA, Latent Print Processing for finger and palm prints and Ballistic Evidence in certain crimes [3].

On a general overall level people, such as a juror or someone following the criminal case in the media, or who personally are victims of a crime, now expect evidence for analysis such as ballistics comparisons, latent print comparisons, DNA analysis and comparison, as well as other specific scientific trace evidence analysis in serious criminal cases such as murders, rapes and robberies. For instance, the public, as shown in Sheldon's graph, really wants to see that DNA analysis was done in most rape cases. Latent print processing for finger and palm prints are highly expected in all cases but especially in breaking an entering or burglary cases. In other words the public is now questioning as to whether these types of evidence are being collected and whether the crime scene was property and fully processed using all available techniques. Besides the Hollywood versions of $\mathrm{CSI}$, the public is also reading and researching current forensic technology and techniques. They are becoming educated and informed, or misinformed as the case may be, through plethora of information out there on what to expect and what they should possibly see in these cases, whether it was collected or available, feasible or even realistic.

Police and sheriff departments are probably the hardest hit in trying to provide the forensic crime scene investigation services expected, if not demanded, by the public. This can be a public relations problem for any law enforcement agency due to the public's perception that their department isn't doing all it can to find the person or persons who committed the crime that effected them personally. Since most serious and high profile crimes will almost always command the full resources of any department, the minor crimes or property crimes are often left unprocessed due to higher volume of property crimes in ratio to persons crimes. As mentioned above these cases are often relegated as "report only" calls for a call taker, a "report only" call taken by a field officer, and in both cases the crime scene ,whether a burglary of a habitation or business, is not processed for evidence, not even latent finger or palm prints. There is a viable solution to assist in crime scene investigation staffing especially for property and minor crimes that can be used by almost any department that can produce real results for case clearance and arrest. An additional perk provided by this solution is the by-product of positive support from the public (or tax payers) regarding their local law enforcement.

According to the Bureau of Justice Statistics, Local Police Department Report of 2003 there are 12, 656 local police departments in the United States. The FBI's Uniform Crime Report of 2005 indicated that cities with a population of 100,000 to 249,999 in the west geographic region of the US employ 1.3 full-time sworn employees for every 1000 citizens FBI UCR, 2005. Well staffed agencies might have as many as 2.3 officers per 1000 such as the Glendale Arizona Police Department City of Glendale, Arizona 2008. Unfortunately there is not such staffing model for crime scene units and the 1 to 3 per 1000 citizen model for police departments is only rough model based on population size. Many other factors come into play in assessing the patrol response. This makes it very difficult to determine how many people are actually needed for a field crime scene response which must be determined by the average amount of various crime scene calls for service over a given period divided by the amount of days and average calls for crime scene service within a monthly period. This will be determined by an administrative study and a rough number of crime scene personnel will be proposed to staff the property and persons crime scene responses. Just as a spike in crime can affect the numbers of officers available for call on any given day, a major crime or a series of minor crime events that are considered a serial event can have a devastating impact on any crime scene unit. With a well trained civilian, sworn or mix of both civilian and sworn crime scene investigators, most major incidents can 
be handled with major call out response. During a major crime scene response incident what becomes of property crimes that still continue during the major crime event? The following idea of a field crime scene response is based on a different method of implementation that can create a sustain solution to working the mounting volume of minor crime scene calls for service and provide a pool of personnel that can assist and be useful during a exigent circumstances involving a large crime scene response.

Field Crime Scene Officer (FCSO) Program (Using limited sworn/police crime scene response to supplement full time crime scene units)

A civilian crime scene unit or a mixed civilian / police crime scene unit can benefit from considering using a concept known as "Field Crime Scene Officers" which involves starting up and maintaining a voluntary "Field Crime Scene Officer Program" or "FCSO Program". The following information can be used by any agencies' current staffing model and possibly provide a solid contingent of trained crime scene investigation practitioners within the department with at least the basic skills required to do the job. In short an officer interested in crime scene investigations is given training and the opportunity to work property crimes as a level one crime scene investigator. While a study is forth coming, the estimated amount of officers interested in participating in a Field Crime Scene Program is approximately $5 \%$ to $8 \%$ depending on how the program is maintained.

Hypothetically in a department with 500 officers this would mean that 25 to as many as 40 officers could volunteer to become Field Crime Scene Officers. If the same department has approximately 17 to 25 fulltime crime scene investigators, this could essentially double the amount of property crime scene processing done. How this would be accomplished starts with having a well trained and qualified fulltime crime scene unit and a coordinator within the unit that is will act as a liaison between the regular Crime Scene Unit and the Field Crime Scene Officers. This coordinator/liaison (possibly one per shift) would oversee the FCSO Program not as a supervisor but as resource, for information, help (if and when needed) in the field, help with equipment and supplies and to ensure that those involved in the program receive on-going training and crime scene schools. Field Crime Scene Programs have been and are currently in use, but the additional component of a liaison/coordinator is not typically a part of the program and may actually be the key to its success. In the case where officers have an intense interest in crime scene as a vocation this could lead to advance levels of certification and permanent assignment. In the case where a department has opted for full-time civilian only certified crime scene investigators this program can be a great bridge creating better coordination and cooperation between patrol officers and the crime scene unit.

To understand any crime scene unit one must understand what a crime scene investigator's job entails. Most departments whether police or civilian employ practitioners of crime scene investigation (CSIs) or Crime Scene Technicians (CST) and not scientist to respond to crime scenes. If a department is fortunate enough to have a degreed (Bachelors or Masters in Forensic Science, Chemistry or Biology) scientist working crime scenes, they would be trained in several disciplines and have one or possible two specialties and paid at higher pay scale. If a forensic scientist occupies the job of processing and analyzing crime scenes and evidence they are generally called a Criminalist. According to the American Academy of Forensic Science the job of a criminalist is described as follows: "Criminalists analyze, compare, identify, and interpret physical evidence. Forensic labs have two primary functions:

I. Identifying $\urcorner$ evidence, and

II. Linking suspect, victim, and crime scene through physical evidence" [4-6].

"The main role of the criminalist is to objectively apply the techniques of the physical and natural sciences to examine physical evidence. Physical evidence may be anything: evidence so small that a microscope is needed to see it, or as large as a truck" [7]. The Criminalist is usually paid a higher salary due to their advanced education and ability to operate lab equipment, analyze trace evidence and testify on the same. A large police department or federal agency might tend to employ a criminalist to respond to major crime scenes in order to ensure that all evidence will be considered, documented and collected for further analysis. Without a law enforcement back ground the criminalist must rely upon observation, scene briefing, and there training and education in forensic evidence analysis to process a crime scene.

While there may be true criminalist working crime scenes in the United States, it is not common for most city and county departments. In other words, those processing crime scenes and collecting evidence in most cities and counties is people who have training or classes in forensic applications and are trained in-house to do the job. Some are police officers and others are degreed and non-degreed civilians who are trained to competency in the basics, a practitioner of crime scene investigations. Merriam-Webster defines a practitioner as "one who practices a profession" [4].

One definition of a crime scene investigator is a position responsible for complex crime scene investigations; responsibility for the evaluation of the scene; uses various types of equipment; develops, secures, and packages physical evidence for scientific evaluation and comparison; prepares detailed reports on the observations and activities at the scene for the law enforcement agency responsible for the investigation of the crime; testifies in court regarding the findings and processing methods used at the scene". Approximately " $70 \%$ of the incumbent's time is spent processing crime scenes, packaging and transporting evidence, attending and photographing autopsies and attending briefings 
and conferences with the police agencies requesting assistance. The remaining time is spent preparing investigative reports, testifying in court, receiving continuing education, instructing classes and maintaining equipment in a state of readiness" [5,6].

These practitioners of crime scene investigations constitute a large portion of the people working crime scenes today in most departments. Traditionally police departments could not afford to hire outside the department and therefore the department used police officers who were sent to training classes in photography, evidence and latent processing, search and seizure of evidence as well as being trained in-house by those already in the unit. Small midsize departments found they could train their officers to do the basic crime scene duties while further analysis of evidence required sending evidence or examinations to a lab by the case detective. While a majority of small and mid-sized departments still use officers as CSIs the trend over the past decade has turned toward hiring civilian crime scene technicians for property crimes and degreed, and/ or certified, civilian crime scene analyst for Persons or Major Crime Scenes such as murders, officer involved shootings, rapes and aggravated robberies.

This trend started for economic reasons because the agency could generally hire the civilian for less money and the person could not reasonable transfer out of the job. Generally the civilian crime scene technician or investigator did not have any hope of career advancement which in some cases, maybe many, caused the person to burn out and quit. The department would then hired another at a reduced rate of pay (or starting pay) and start the process all over. The police officers on the other hand who became "burned out" or disgruntled for whatever reason, could transfer out of the crime scene unit back out to the field or another job within the department and continue as an officer. While the crime scene training is still resident within that officer, it is, in many cases, not being used to its full potential, if at all. In other words, the officer trained to competency in crime scene investigations, no longer uses these skills as a part of their current job.

As a result the department must train another officer to competency which will take time thereby causing the crime scene unit to be short staffed. Of course, having crime scene training for any field or patrol officer is a plus as they respond to calls for service and can possibly be put to use in a different way. If properly approached, the officer transferring out of crime scene might be will to participate in the Field Crime Scene Officer Program thereby returning to the field but still using those skills learned as a result of their training. The trend toward civilianizing is no longer predominantly an economic issue. Law Enforcement agencies are looking for degreed, certified crime scene investigators and paying them a good salary or hourly wage. Police administrators are currently high professional standards from civilian crime scene investigators and like the idea of hiring them. Without the escape to another area with the department the civilian CSI tends to concentrate their efforts on their vocation and on-going training. Some agencies have even started a "pay point" career path for civilian crime scene investigators based on the International Association for Identification (I.A.I.) Certification Program.

The I.A.I. has three levels of crime scene investigation certification that require increasing levels of experience, education and training as well as a fairly difficult exam. These levels are as follows:

a) Certified Crime Scene Investigator (CCSI)

b) Certified Crime Scene Analyst (CCSA)

c) Certified Senior Crime Scene Analyst CSCSA) $[7,8]$

"The CSI qualifications include the following: a. must have a minimum of one year in crime scene related activities: $b$. must have completed a minimum of 48 hours of Crime Scene Certification Board approved instruction in crime scene related courses within the last five years, plus a 200 question test based on two applicable books that must be completed in three hours" [8].

"CSA qualifications include the following: a. must have a minimum of three years in crime scene related activities: $b$. must have completed a minimum of 96 hours of Crime Scene Certification Board approved instruction in crime scene related courses within the last five years, plus a test with 300 questions based on three listed books completed in four hours" [8].

"The senior CSA qualifications include the following: a. must have a minimum of six years in crime scene related activities: $b$. must have completed a minimum of 144 hours of Crime Scene Certification Board approved instruction in crime scene related courses within the last five years and must have authored or coauthored an article on some phase of crime scene investigation published on a professional journal, or made a presentation of some phase of crime scene to a professional organization, or be an active instructor in some phase crimes scene investigation who is currently teaching at least once a year or submit a court transcript from an actual case in which the applicant gave testimony on some phase of crime scene investigations. The test for this certification is a 400 question test also based on three listed books, and must be completed in five hours" [8]. The Arlington Police Department located in Arlington Texas has a 10-person civilian only crime scene unit that employs this skill base pay point model as a career path for their crime scene investigators. Beat officers are issued a small latent processing kit and some a digital camera and are tasked with working minor or property crimes and simple assault documentation. With the minor calls being worked by patrol officers, the major crime scene calls are worked by the full time civilian crime scene investigators. Arlington's crime scene unit has a three level pay plan for their crime scene personnel (Figure 2). 
Journal of Forensic Sciences \& Criminal Investigation

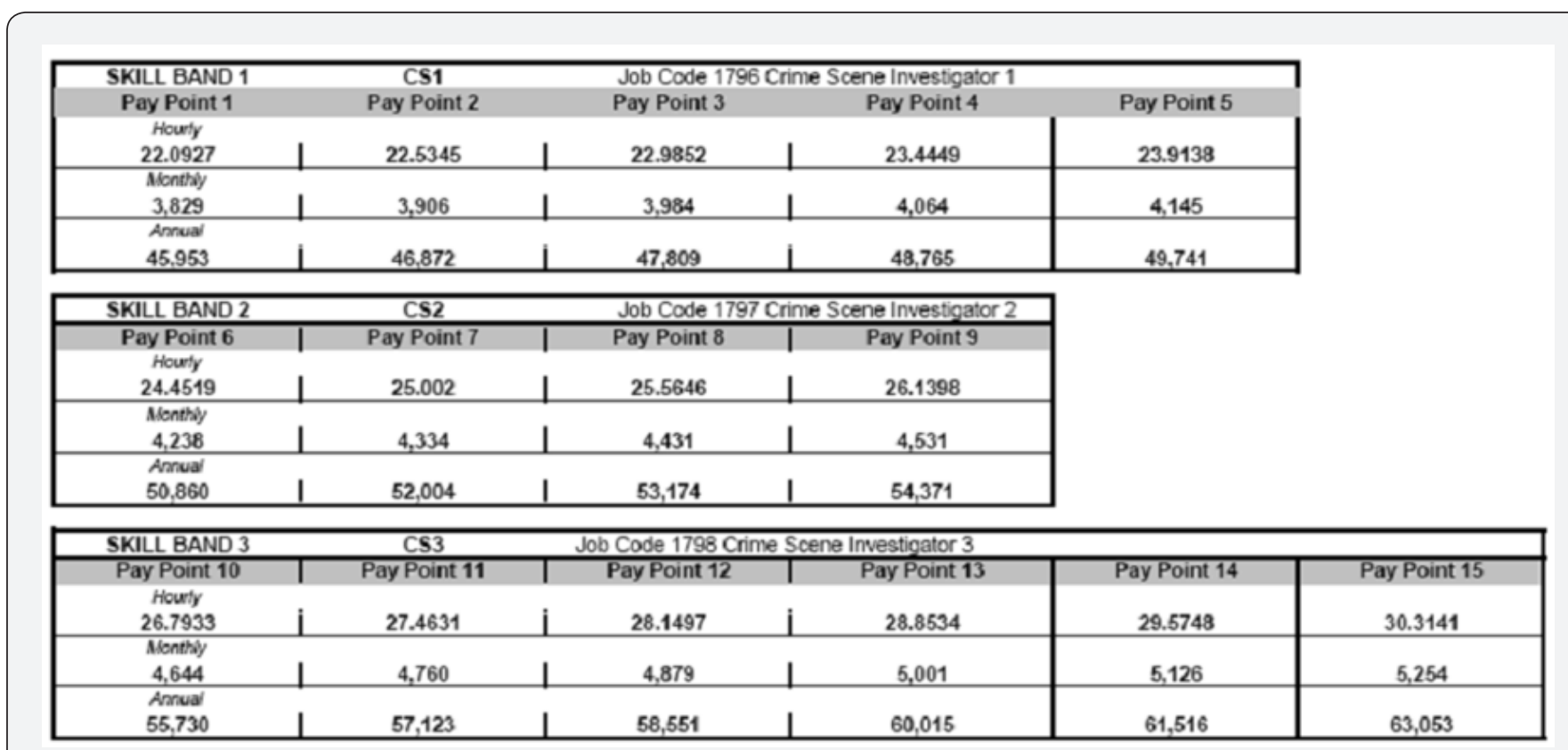

Figure 2: FY 2008Skill Base Schedule (Crime Scene) Eff: 10/82007.

The Arlington Police Department Crime Scene Unit use Crime Scene Investigator (CSI) 1, 2, and 3, and job codes that specifically outline the training needed to achieve the specific pay for the "skill band". These are based on the I.A.I. qualifications and a person achieving the Senior Crime Scene Analyst certification is placed in the skill band 3 or CSI-3 position. A second advanced certification, such as Certified Latent Print Examiner (CLPE), Certified Blood Pattern Examiner (CBPE) or Certified Footwear Examiner (CFWE) places the CSI-3 at the top of the pay scale at $\$ 63,053$ a year or $\$ 30.3141$ an hour (COA, APD Policy, 2007). Many would consider this an above average salary. Arlington's example may not be the norm, but it certainly signals a trend to civilianized and create a step pay structure that encourages and rewards increased skill and training. The Arlington Police Department mandate use of police officers for minor crime scene calls however only issue them small powder and brush processing kits. There is some success in this program however there are many that do not use their kits and the expense of supplying a kit to all patrol officers may be wasted on some.

Law enforcement agencies have many descriptions of the crime scene investigator job which may include the following: Crime Scene Investigator (CSI), Crime Scene Technician (CST), Crime Evidence Technician (CET), Crime Scene Analyst (CSA) and crime scene Detective (usually referred to as a Detective assign to the Crime Scene Unit). These are only a few of the current terms in use that encompass the job of crime scene investigation. A fairly concise definition was given in the earlier part of this paper and the job at the crime scene analyst level will probably include all of the duties listed. A general description of the crime scene investigator typically used by most departments to perform these duties is a person specially trained to document, collect and process evidence at crime scenes. A trained crime scene investigator should be competent in crime scene photography, evidence identification and preservation, latent print processing, proper collection of biological samples and trace evidence if required, and proper handling and packaging of physical evidence for storage and lab submission.

For the purposed of this paper the terms crime scene investigator (CSI) and crime scene analyst (CSA) will be used as a standard for establishing a possible tiered system for a crime scene unit that will include these terms (CSI, CSA). They are derived from the current certification programs for crime scene investigation approved by the International Association for Identification. This organization is the "world's oldest and largest forensic science/association", and its "programs are accredited by the Forensic Specialties Accreditation Board (FSAB). The FSAB was established in 2000 to accredit those forensic certification programs that require a strong base of knowledge, skills and abilities. FSAB reviews certification programs by conducting a rigorous review of the requirements, testing, procedures and business practices of the certifying body to ensure that the programs meet the required high standards" [8].

Often CSIs are primarily tasked with the functions of taking photographs or digital images of crime scenes or victims of assault and processing for latent prints, especially in the case of property crimes such as the various forms of burglary. The term "latent" according to the Merriam Webster Dictionary means "present and capable of becoming though not now visible", while a simpler definition might be "not visible to the eye" [7]. Latent prints are generally referred to as chance impressions left by a 
person fingers and palms, due to moisture secretion from the pores of the friction ridge skin or transfer oils or lipids, that are present at crime scenes but cannot be seen (readily visible by the naked eye) without some sort of enhancement. After observing the substrate using lighting techniques, a CSI will often accomplished making these invisible prints visible by applying black fingerprint powder (or other types and colors of fingerprint powder) using a soft fiberglass or feather brush. The now visible print is collected using fingerprint lifting tape which is then transferred to a while card. All of the pertinent case information is written on the card with the transferred latent print. These cards containing the processed print are often referred to as latent prints as well (even though they are now visible).

The reason for describing this process is due to the fact that it is probably the most common type of evidence collected at property crime scenes and also some of the most valuable evidence that can be readily analyzed and utilized by examiners and detectives. The latent processing described above is a recognized manner of finding latent finger and palm prints at crime scenes and is generally an accepted practice of collecting this type of evidence for AFIS (Automated Fingerprint Identification Systems) entry and eventual comparison to possible known subjects by latent print examiners.

Advanced duties of a crime scene investigator or analyst can often include the following: thorough documentation crime scene details such as tool marks, shoe and tire impressions, bullet trajectory and other complicated evidence using macro photography and/or digital imaging, rough and finish computer CAD sketching, complex evidence collection such as shell casing placement and blood spatter evidence, scene and evidence processing for latent prints that include chemical and dye stain techniques, location and collection trace and biological collection using ALS (Alternate Light Sources, and portable laser equipment), secure evidence transport, chain of custody, and proper packaging and storage of biological evidence and securing evidence with the Property/Evidence Section of their department. A crime scene investigator may be tasked with lab processing of evidence collected at scenes for latent finger and palm impressions using more complicated methods than powder processing such as cyanoacrylate (super glue) fuming, chemical processing and the use of macro-photography to capture development of possible latent print images. How these duties are carried out typically indicate what kind of crime scene response a department is willing or able to afford. In real terms, a CSI working a residential burglary, after performing a brief informational walk through, might take photos of the scene that include the point of entry, point of exit as well as evidence and areas within the residence reportedly disturbed by the suspect that may be processed.

The CSI might then process the scene for latent prints starting with the point of entry and then moving into the residence working on items reportedly touched by or moved by the suspect. If latent prints are discovered as a result of processing these would be transferred from the surface to a card and marked with the area lifted, date and time of the lift as well as the other pertinent case information. These latent print cards would be collected into a secure envelope and submitted for AFIS entry and possible latent print comparisons if suspect is developed. The CSI would then determine if any other pertinent evidence needed to be collected for further processing or possible better processing at the CSI processing lab. Biological evidence should be collected even though this is a property crime. Better to have for analysis later than not to have it at all. The above scenario describes a scaled down version of working a regular residential burglary. Some would say too much was done while others would counter that not enough was done. Taking digital images or photos of the latent prints prior to lifting might be an example of something that could be done that is typically not done in property crime cases such as burglaries. Taking photos or digital images is considered by some to be "overkill" citing that processing for latent prints is all that truly needs to be done and if latent prints are developed and submitted the latent print cards themselves are the best evidence to present in court. The crime scene response for person crimes, or major crimes, must obviously be much more detailed due to the serious nature of the offense. This is no different than what any law enforcement agency does when deploying its patrol forces or investigation efforts.

Most law enforcement agencies have two major divisions for Investigations Bureau or Detective Divisions; Property Crimes and Persons Crimes. Each division usually has subsets such as a Homicide Unit in the Persons Crime Investigative Bureau and an Auto Theft Unit in the Property Crime Investigative Bureau. In large cities these units can be further broken down into beat areas from which cases flow that are the detective's responsibility to investigate. Both divisions generally contain significantly more personnel than a crime scene unit. How does a department consider the amount of staff needed to provide a workable crime scene investigation response? Many departments handle this situation differently from having only non-sworn civilian crime scene personnel while others only entrust this to sworn or police crime scene investigators.

There is no doubt that how many people needed (staff) to provide a reasonable CSI response will depend on the size of the population, tax base, and the amount of property and persons crimes that occur with the geographical area that is the responsibility of a particular law enforcement agency. While some larger departments have crime labs and crime scene units together in a single area, this paper's main concern is providing a workable solution to the field crime scene investigation response. The crime scene investigation response, unlike any other area in law enforcement, lends itself to an interesting collaboration between civilian specialists, police officers, and sheriff deputies 
that not only assist the department in providing a solid crime scene investigation response but provide a contingency in multiple crime scene circumstances or a large crime scene event such as highway shooting scene with multiple fatalities and combine accident events.

Even for a large busy city, the amount of crime scene personnel is not necessarily set at a particular number based on population size or even calls for service.

There is some statistical data used but the fluctuation of crime trends make it hard to pin down how many crime scene response personnel are needed. When one looks a staffing for police in any given city one will find that there is not a set formula to determine the amount of police officers, sheriff deputies or other law enforcement officers needed for patrol is generally determined by the size of the population of those being served. Using the model mentioned earlier, a population of approximately 300,000 might have a patrol force of 300 if it is determined that one police officer is needed for every 1000 people. If the city council, city manager, or other governmental body determines that they want twice the amount of coverage, that is two officers for every one thousand, then the patrol operations would need 600 street officers (or patrol force) to serve the public. The question is then how is it determined the amount of detectives and crime scene investigators needed for the same population? Patrol or street officers are needed for specific functions such as calls for service, peace keeping functions and law enforcement operations, in other words, they are on the street to meet the public's immediate need, to enforce the law and try to deter criminal activity.

Criminal investigators and crime scene personnel have a different function in that they follow up on reported crimes, analyze crime scenes and evidence and then present these cases with the alleged suspect to court for consideration of prosecution, exoneration and punishment. It would seem logical and simple to staff a particular law enforcement function by how many calls for service that area services annually. Unfortunately even in patrol functions this solution simply cannot suffice for exigent circumstances such as a riot or crime wave, or even a smaller but significant problem as a multi-victim shooting incident such as the recent Virginia Tech incident Problems in staffing criminal investigations or detective units share some commonality to staffing crime scene investigation units, however there is a distinct difference in the requirements from the type of personnel needed for the job to the actual job being performed. The population model used for patrol officers or street law enforcement is generally not used to determine how many criminal investigators (detectives) and crime scene investigation personnel that are needed to serve a given population.

The most important consideration in considering how to staff crime scene investigations is to understand how crime scene investigations are performed and what level of training is needed by personnel to complete the various tasks involved in crime scene matters in a competent manner. In considering starting, changing or upgrading the staffing of an existing crime scene investigation unit, the same premise still applies. The Technical Working Group on Education and training in Forensic Science, TWGED, studies and makes recommendations for forensic training states in its 2004 report states, "the results of forensic investigation often can be the acquittal and conviction in a court of law" NCJRS, TWGED 2004.

Crime Scene Investigations is generally different than Forensic Laboratory work. Crime scene investigation is defined as a physical response to crime scenes by specially trained personnel for the purposes of documenting the scene, identifying and collecting evidence for further analysis as well as documentation, processing the scene for latent prints, shoe and tire impression evidence, gunshot evidence, blood spatter evidence, trace evidence, and possible biological evidence. Other techniques that can be involved in crime scene investigation and analysis include crime scene reconstruction and as well as evidence analysis [9] Those who perform crime scene investigations or part of the of the crime scene investigation functions have educational requirements that span from a high school diploma to bachelor's degrees, with an emphasis or preference of the sciences.

Forensic Laboratory personnel are often but not always forensic scientists that have a strong back ground in natural sciences and academic degrees based on biology and chemistry. They perform analysis of drugs, DNA samples, trace and toxicological evidence.Generally forensic laboratory personneldo not respond to crime scenes. Their function is critical to criminal investigations but is generally in the chain after crime scene investigation personnel have performed their function. Although not generally considered to be scientist, latent print examiners, ballistic examiners, shoe and tire impression examiners and hand writing analysis can be part of a forensic laboratory or part of a crime scene unit. While some law enforcement agencies have a "crime lab" and a "crime scene response unit" many do not have a full forensic lab within the department. Large police departments, state and federal law enforcement agencies trend toward having full or partial forensic labs and crime scene response units, since funding is available to do so and these agencies prefer to perform their own evidence analysis. The use of DNA evidence is such an important factor in criminal cases that every state now authorizes the collection of DNA samples from convicted offenders along with the establishment of CODIS (Combined DNA Index System) databases where they currently do not exist on the state level (Federal Bureau of Investigation 2007b) [10-12]. Midsize and smaller law enforcement agencies are forced to scale down their efforts to a physical crime scene response sometimes by the same person that is the responding officer and or detective. There trace and biological evidence is sent to the county or state lab. 


\section{Solution}

So where does the Field Crime Scene Officer fit into all of the above? He or she would be considered a Crime Scene Investigator, level one. They would typically attend classes in crime scene photography; evidence processing that covers the basics in powder processing and the different substrates, as well as other courses later in their training regarding the recognition and preservation of shoe and tire evidence and other topics that would apply to property crimes. If great interest is shown in the discipline, advanced classes could be used as a perk (and encouragement) of the position which would be symbiotic to the agency and officer who would then have advanced knowledge and training to apply in the field when needed for called upon by the Crime Scene Unit. Just a field officer is paired with a training officer and taken on a graduated scale of increasing responsibility, so would the field crime scene officer with an experienced Crime Scene Investigator from the unit. This training period could be 4 to 6 weeks at which time the Field Crime Scene Officer is sent back to patrol with a camera, hopefully digital, and a scaled down crime scene processing kit, and be available to work property crime scene calls and take photos for minor or simple assaults.

After initial training is complete the Field Crime Scene Officer should have some weekly contact with their shift liaison to discuss any problems or equipment needs and any help requested should be given. A suggested commitment period for a Field Crime Scene Officer should be six months to one year. At a six month assessment with the liaison if the Field Crime Scene Officer no longer wants to participate in the program they should turn in their equipment and be released. If they wish to continue until their year is complete another assessment and meeting will occur. If release is requested at this point the officer should be released from the program as well, turning in their equipment for another to try their hand at it. There will be those who truly enjoy the process of performing simple crime scene work and will become incredibly efficient and effective at the task. Some may even desire to transfer into the Crime Scene Unit if the unit has sworn officers and this is a great pool of applicants for the position.

There is much more to developing this program than this paper will allow, however the main components involved in creating a successful Field Crime Scene Program using patrol or beat Officers is based on some important founding principles. The first and foremost is ensuring that the program is a voluntary enlistment that the officer must request to be considered. Almost as important is the use of an active and energetic liaison/ coordinator (maybe on each shift for larger departments) that uses service and teaching as a way to encourage the Officer's participation in the program. Officers involved in the Field Crime Scene Program should be given the appropriate consideration regarding the time it takes to process scenes and complete the paperwork and latent prints cards associated with being involved in the program. Their field supervisors should take into consideration the amount of crime scene calls in a given month when calculating their production. Officer participating in this program, that stay in more than one year should be sent to update training and considered for outside schools to enhance their crime scene knowledge. Last but not least, if possible an hourly benefit either in pay or some form of comp-time could be used as a reward for the effort the officer puts forth in performing minor crime scene duties while also working a beat or district.

The idea of a Field Crime Scene Officer Program is a workable solution to an on-going problem of the need for more crime scene response regarding property crimes from burglary of a motor vehicle, auto theft recovery, minor residential and business burglaries as well as calls for pictures only on simple assaults. Officers are the first responders to these calls and many already have developed a sense of how a particular crime was committed. They are often tasked only with taking a report and moving on to the next call. A Field Crime Scene Officer could indulge him or herself in "looking for clues" by being allow to process that burglary scene or the recovered stolen auto. One could image in the satisfaction that a Field Crime Scene Officer would receive if advised, by their liaison, that the latent prints they collected from a burglary scene were identified to a suspect and warrant was issued. Being a patrol officer, they might even know the suspect and affect the arrest. This scenario is a real one and has happen on many occasions. While the trend to hire civilian crime scene investigators may be a good one, the use of the field or beat Officer should never be underestimated. A collaborative effort such as described above between any crime scene unit and the field patrol officers can only produce positive results in suspect apprehension, crime prevention, and public approval. It can truly be a win-win situation.

\section{References}

1. US Department of Justice/Office of Justice Programs/Bureau of Justice Statistics (2004).

2. John A shcroft, Deborah J Daniels, Sarah V Hart (2004) US Department of Justice, Officer of Justice Programs, National Institute of Justice p. $1-64$.

3. Sheldon DE (2008) Does the CSI Effect Really Exist? National Institute of Justice p. 1-14.

4. The American Academy of Forensic Science (2010).

5. International Crime Scene Investigators Association (2006).

6. International Crime Scene Investigators Association (2006).

7. Merriam-Webster (2007) latent defect.

8. The International Association for Identification (2010).

9. Schmallegar F (2007) Criminal Justice Today: An Introductory Text for the Twenty-First Century. Prentice Hall, New Jersey, USA.

10. Muraskin R, Roberts AR (2005) Visions for change ( $5^{\text {th }}$ edn). Prentice Hall, New Jersey, USA.

11. City of Arlington Police Department, Pay Structures (2007)

12. The Bureau of Justice Statistics (BJS) (2006) Office of Justice Programs. 
This work is licensed under Creative Commons Attribution 4.0 License DOI: $10.19080 / J F S C I .2017 .04 .555640$

\section{Your next submission with Juniper Publishers} will reach you the below assets

- Quality Editorial service

- Swift Peer Review

- Reprints availability

- E-prints Service

- Manuscript Podcast for convenient understanding

- Global attainment for your research

- Manuscript accessibility in different formats

(Pdf, E-pub, Full Text, Audio)

- Unceasing customer service

Track the below URL for one-step submission https://juniperpublishers.com/online-submission.php 